\title{
The Differences between English and Indonesian Lecturer in the Classroom Interaction Based on Sinclair and Coulthard Model
}

DOI: https://doi.org/10.47175/rielsj.v1i3.143

\section{| Christine Helena Natalia ${ }^{1, *} \mid$ Khairunnisa br. Batubara ${ }^{2} \mid$}

${ }^{1,2}$ Faculty of Languages and Arts, Universitas Negeri

Medan, Medan, Indonesia

${ }^{*}$ christinehelena@unimed.ac.id

\begin{abstract}
This study was about IRF (Initiation-Response-Feedback) analysis on classroom interaction between English and Indonesian lecturer with students. The aimed of this study were to describe the processes of Initiation-Response-Feedback are employed by the English and Indonesian Lecturers with students in classroom interaction based on Sinclair and Coulthard Model. This research used qualitative research. The data of this study were the utterances that expressed by the English and Indonesian lecturer with students in thelearning process. The source of data was English and Indonesian lecturer with the students in STKIP Budidaya Binjai. The data were collected in five ways by Rymes (2009) observing, recording, transcribing, interviewing and analyzing. The data were analyzed based on Sinclair and Coulthard (1975). The result of this study were English subject, the lecturer initiaton was the highest appear in classroom interaction. The students felt enthusiastic in learning it although they had problem in pronounciation and write words but they want to try to do the task given by the lecturer. Lecturer initiation as the highest appear in classroom interaction. The competition as the technique of teaching that lecturer used in this learning process just made one student of each group that become active in share their opinion. The other students felt ashamed to share their opinion because of afraidness to get bad score from the lecturer. KEYWORDS

Classroom Interaction; Initiation-Response-Feedback; Sinclair and Coulthard
\end{abstract}

\section{INTRODUCTION}

Interaction is an activity that usually conducts in classroom and it has an important role to build communication between lecturer and students as stated by Walsh (2011) that communication is a central to all classroom activity. According to Brown (2001), interaction is at the heart of communicative competence. According to Hall (2011), classroom interaction is a term that used to analyze what goes on among people in classroom when language is involved. Classroom interaction is an activity of mutual action in the teaching and learning process in which there is a relationship between students and lecturers to achieve a goal.

Nowadays, the common interaction that occurred in the classroom was students would participate to talk if the lecturer initiate and asked them to talk. Whereas students must be have big chance to talk more and students to be more active to interact and to participate during the teaching and learning process. 
When Indonesian lecturer just need once to ask the students to be active in the class, the English lecturer must try more than once to lead the students to be active in the class. Indonesian lecturers do not really need more energy to initiate students in participate throughout the lesson. Since Indonesian lecturer use the same language with the students, they can understand the lecturer's intention and be able to give respond faster. It is very different from English lecturers who must try to initiate their students to be active in the learning process. English lecturers must repeat the sentence or change it from English to Indonesian so that students can understand what is meant by the lecturer and so that they can respond to the lecturer.

\section{LITERATURE REVIEW}

\section{Teaching English at University}

English is taught as a foreign language in Indonesia but it is not used natively in social life. It is taught from elementary school until in university. In junior high school, English is taught in one hundred and eighty minutes which is counted as four lessons per week in every class following the Curriculum 2013 system.

\section{Classroom Interaction \& Learning Process}

According to Brown (2001), interaction is at the heart of communicative competence. Goronga (2013) asserts that the clasroominteraction makes the students participating in the teaching and learning process. According to Hall (2011), classroom interaction is a term that used to analyze what goes on among people in classroom when language is involved.

Classroom interaction is a two-way interaction process between lecturer and students during teaching and learning process exchange of thoughts, feelings or ideas as a result of input and output of language which is acquired by them through interaction.According to Robinson (2005), interaction in the classroom is channeled through nonverbal interaction. It refers to body language between lecturer and students in classroom. There are many functions of non-verbal interaction in the classroom, such as expressing emotion, communicating personal attitudes and supporting speech.

Kang (2013), the more lecturer uses English in the classroom, the more students imitate and use it. Being proficient, the lecturer can also stimulate the students to participate in oral interaction in the classroom (Consolo, 2006). On the other hand, student factor may play prominent role in classroom interaction. Student's level of proficiency, character, intelligence, confidence and motivation are elements that may influence how students communicate and interact with others in the class.

According to Uzer (2004) there are many factors that influence lecturer can build an effective classroom interaction during teaching and learning process. They are warmth and enthusiasm when lecturer giving task and take care of students' activity, the using of learning media, technique and strategy of teaching to gain the students' interest in learning, flexibility of lecturer to create good atmosphere between lecturer and students in classroom even out of the classroom, and giving positive motivation and support to encourage students in learning.

\section{Sinclair and Coulthard's Rank Scale}

The model produced by Sinclair and Coulthard derived from the rank scale model originally developed by Halliday, which initially concentrated on theory of grammar. Lesson takes place in the classroom from the lecturer until lecturer leaves and is made up of a series of transactions, which in turn is made up of a number exchange. Exchange 
generally consists of the IRF (Initiate-Response-Feedback) exchange pattern and is realized by elicting, informing, and directing moves. IRF pattern describes a reciprocal relationship between lecturer and students in the classroom. Lecturer raises a question, then students answer it, and the lecturer gives an evaluative follow-up or feedback before raising another question are referred to as initiation, response, and follow-up or feedback. Exchange then, is made up of a number of moves. Moves are made up acts. Acts are the smallest units of analysis and can take on many different functions within the move.

The IRF itself is the patterning of the classroom interaction. The sequences pattern during classroom activities is lecturer initiation which followed by student response and the last exchange was lecturer feedback. In this case, asking question was used to initiate interaction to the students, so students could involve responses actively then lecturer involved confirmation to the responses.

Dayag et al. (2008) initiation is the lecturer ask a question or action to initiate students to do interaction in classroom. It is the effort of the lecturer in pushing the students to drop their selves in a communication or interaction. Initiation is the opening of discourse. Initiation that is conducted by lecturer is realized by ten exchanges: lecturer elicit, lecturer inform, lecturer direct, re-initiation (i), re-initiation (ii), check, repeat, reinforce, and boundary. While the initiation that is conducted by students is realized by students elicit and students inform. An exchange is formed by at least Initiation and response.

Dayag (2008) state that response is represent the lecturer initiate in response of initiation move by participants act. It means that the students do interact to response the lecturer stimuli. Response is the answer or reply of the discourse, it is important to remember that in the exchange, both initiation and response could be conducted by lecturer and students. The response from the lecturer is expected in student's elicit exchange. While the response from the student is expected in mostly exchange initiated by lecturer. Response moves is actually performed by the students following the initiation which produced by the lecturer.

According to Dayag (2008) that feedback completes the cycle as it provides closure to the initiation and response. It means that students get immediately the correction or evaluation for their response. Feedback is the follow-up from the response which is conducted mostly by lecturer and very rarely by students. When a student replies lecturer's question, the other students may not hear clearly sometimes. So, the lecturer needs to repeat the students words to make it clear to all students in feedback, what is more important is that the lecturer should give "feedback" to the student's answer. The last exchange of a turn which aims to give feedback to students' response

\section{RESEARCH METHODS}

This research was conducted by using descriptive qualitative research. As Crewel (2007) states that descriptive qualitative research describe the phenomenon being studied, conditions or relationship that exists. It is designing to get a better understanding about the phenomenon of IRF model in the lecturer and students interaction in classroom. The data was focused on the teaching learning process by analyzing the verbal interaction through conversation among lecturer and students by using Sinclair and Coulthard model.

The data of this study was the utterances which expressed by the English and Indonesian lecturer with students in classroom. The sources of data were English and Indonesian lecturer with 30 students in STKIP Budidaya Binjai during the English and Indonesian language classroom. 
The technique for collecting data of this study was recorder technique. It was used to record the the interaction between lecturer and students in English and Indonesian subject. Researcher record the process of teaching and learning with the aimed to get accurate information about the using of IRF in English and Indonesian subject. Then, these data was converted into written transcription.

The instrument for collecting data of this study was collected by using observation and documentation. Observation is an activity that pays attention accurately, records phenomena that arise, and considers the relationship between aspects in the phenomenon. In this study researcher was used audio recorder as the instrument for doing observation. The documentation instrument is develop for research using a content analysis approach. In this study researcher was used the transcript of utterances by English and Indonesian lecturer with the student. After collecting the documents, the researcher was analyzed the process of Initiation-Response-Feedback are used in the classroom.

The technique for analyzing data in this research was analyzed by using the data analysis from Rymes (2009). Five basic steps: observing, recording, transcribing, interviewing and analyzing those transcripts as the foundation for the work of classroom interaction analysis.

\section{RESULTS AND DISCUSSION}

The overall utterances produced by the lecturer were 356 utterances in English subject and 196 utterances in Indonesian subject. During the teaching learning process in the classroom, lecturer and students produced all the types of IRF technique were contained lecturer inform, lecturer direct, lecturer elicit, student inform, student elicit and check.

\section{Lecturer Inform}

Lecturer inform is used to convey facts, opinions, ideas, new information to the students. It was found that lecturer inform produced by the English lecturer was 7 times. The lecturer inform produced by the Indonesian lecturer was 13 times.

\section{Lecturer Direct}

Lecturer direct is used to get the student to do but not to say something or in other word it is used to elicit a non-verbal response from the students. It was found that lecturer direct produced by the English lecturer was the most dominant type of initiation which was 63 times.

\section{Lecturer Elicit}

Lecturer elicit is designed to obtain verbal contributions from students or to elicit a verbal response from a student.It was found that lecturer elicit produced by the lecturer was 58 times. Lecturer elicit produced by the lecturer was 25 times.

\section{Student Inform}

Student inform is used to convey facts, opinions, ideas, new information to lecturer or other students. It was found that studentinform produced by the student was 17 times. Student inform produced by the student was 22 times.

\section{Student Elicit}

Student elicit is designed to obtain verbal contributions from students or to elicit a verbal response from a student. It was found that student elicit produced by the student was 17 times. Student elicit produced by the student was 5 times. 


\section{Check}

Check is used to discover how well the children are getting on, whether they can follow what is going on, whether they can hear. It was found that check produced by the lecturer was 42 times. Check produced by the lecturer was the most dominant type of initiation in Indonesian subject which was 30 times.

English lecturer used lecturer direct dominantly to make sure the students understand the instruction in doing the task. It also be the lecturer's method in teaching to make the students active in all the classroom activity. Indonesian lecturer used check dominantly to make sure the student's knowledge about the topic of learning is correct. Lecturer also compare every student's knowledge to gain more information to share.

\section{Discussion of findings}

After analyzing the data, it was found that in English subject the lecturer and students seldom used English in the classroom. The lecturer responded various answered by using English and Indonesian Language to make students understand the lesson and because the students can't speak English well. The lecturer always tried to speak English in the classroom interaction and always looking for each students whether there is a difficulty in the learning process. Lecturer used repetition as the technique of teaching, lecturer asked the students to finished one task with some part. First, lecturer and students read the task together. Second, lecturer asked the students read it once again by themselves. Third, lecturer let the students to do the task in a piece of paper by group. Four, lecturer asked the students to move the right answer to the student's notebook. Last, lecturer asked some students to read the task again. Most of interaction between lecturer and students started by lecturer question. This technique made most of students active to raise their hand to try to give their own answer. When one student gave the respond to the lecturer's question then the lecturer will initiate the other students to share new answer to compared. Some students made interaction when lecturer giving task. Students would asked the lecturer about the instruction how to do the task and asked the lecturer about the student's work have correct or not. The feedback that usually gave by the lecturer were the correction about the student's pronounciation and how to write the correct words.

In Indonesian subject it was found lecturer used the competition as the technique of teaching to make the students active in participating in the learning process. This technique made just one from each group discussion that active to raise their hand in share the answer to get score. In this interaction sequence, lecturer controls interaction in classroom through initiating discussion and posing questions to students. Lecturer collected the answer from each student's group as the studentsresponded questions given by lecturers, then lecturer finishes the interaction sequence by giving feedback on student's response.

The IRF pattern in the classroom interaction for studying English and Indonesian subject can be seen in Table 1 below.

Table 1. The Pattern of IRF

\begin{tabular}{ccc}
\hline Types & English & Indonesian \\
\hline Lecturer Initiation & 238 & 108 \\
Students Response & 264 & 167 \\
Lecturer Feedback & 48 & 68 \\
\hline Total & 550 & 343 \\
\hline
\end{tabular}

From the table above, it can be conclude that in English subject, the lecturer initiaton was the highest appear in classroom interaction. The students felt enthusiastic in learning it 
although they had problem in pronounciation and write words but they want to try to do the task given by the lecturer.

In Indonesian subject, the table showed lecturer initiation as the highest appear in classroom interaction. The competition as the technique of teaching that lecturer used in this learning process just made one student of each group that become active in share their opinion. The other students felt ashamed to share their opinion because of afraidness to get bad score from the lecturer.

\section{CONCLUSION}

From the data it found that lecturer initiation become the most of type that appear in classroom interaction both of English and Indonesian subject. The initiation of lecturer direct is the dominantly used by English lecturer, while lecturer's check is the dominantly used by the Indonesian lecturer. Although students faced unfamiliar vocabularies which are used in the textbook, students felt interested to do every task in English subject. It is contrast with students in learning Indonesian subject, since one student of each group discussion that become more active, it makes the other students not interest to follow the learning process. The other reasons that make students did not active in the Indonesian subject is students feel afraid to get bad score if they share the wrong answer.

It can be concluded that the kind of lecturer-student interaction in the classroom interaction is reflected by lecturer initiation in which the lecturer initiates the students by giving the questions, soliciting information and identifying the students who have the next turn to answer. In the case of the dominance of student response, it will depend on what the material of the classroom lesson and how the lecturer's way in stimulate the students to be active. If the material in classroom lesson is quite easy the student participation will occurred frequently.Lecturer can use the initiation as a way in stimulate students to make them interested in learning, so the frequence of student response is increasing.

\section{Suggestions}

It is better if lecturercan stimulate students to use English in the teaching learning process. The classroom interaction between lecturer and students can be interesting if there is two ways communication. But if the lecturer too dominant, of course the students will be passive in the class. And the lecturer should improve the students English by having practice and supporting them to be brave to speak English.

The students should improve their English and dare to speak up English in the classroom. If they make mistake when they speak English, the lecturer will be kindly to improve their mistakes. They should create their own opportunities and find strategies to build their confidence.

The next researcher should to conduct further studies about classroom interaction based on Sinclair and Coulthard model which will be very useful reference to the lecturers' and students' need in classroom interaction.

\section{REFERENCES}

Brown, H. (2001). Teaching by principles: An interactive approach in language pedagogy (2nd ed.). New Jersey: Prentice Hall.

Consolo, D. A. (2006). Classroom Oral Interaction in Foreign Language Lessons and Implications for Lecturer Development. Linguagem \& Ensino, 9(2), 33-55. 
Dayag, D.T., Gustilo, L. E., Flores, E.G., Borlongan, A. M., \& Carreon, M. C. (2008). Classroom discourse in selected philippine primary schools. British Council

Goronga, P. (2013). The Nature and Quality of Classroom Verbal Interaction: Implications for Primary School Lecturers in Zimbabwe. Part-II: Social Sciences and Humanities.

Hall, Graham. (2011). Exploring English language teaching: language in action. New York: Routledge.

Kang, D. M. (2013). EFL Lecturers' Language Use for Classroom Discipline: A Look at Complex Interplay of Variables. System, 41(1), 149-163. https://doi.org/10.1016/j. system.2013.01.002.

Rymes, B. (2008).Classroom Discourse Analysis: A Tool for Critical Reflection. Cresskill, NJ: Hampton Press.

Robinson, Helja. (2005). The ethnography of empowerment: the transformative power of classroom interaction. London: The Falmer Press.

Sinclair, J. M., \& Coulthard, M. (1975). Towards an Analysis of Discourse: The English Used by Lecturers and Pupils. London: Oxford University Press.

Usman, Moh. Uzer. (2004). Menjadi Guru Profesional. Bandung: Remaja Rosda Karya.

Walsh, Steve. (2011). Exploring classroom discourse language in action. London: Routledge Taylor and Francis Group. 